\title{
UNIFIED BASIC SOFTWARE AND HARDWARE COMPLEX FOR PRECISION ENERGY-SAVING SYSTEMS OF AUTOMATIC REGULATION AND CONTROL
}

Kaniuk G. I. - Dr. Sc., Professor, Head of the Department of Heat and Power Engineering and Energy Saving Technologies of Ukrainian Engineering and Pedagogics Academy, Kharkiv, Ukraine.

Mezeria A. Yu. - PhD, Associate Professor, Associate Professor of the Department of Heat and Power Engineering and Energy Saving Technologies of Ukrainian Engineering and Pedagogics Academy, Kharkiv, Ukraine.

Kniazieva V. N. - Post-graduate student of the Department of Heat and Power Engineering and Energy Saving Technologies of Ukrainian Engineering and Pedagogics Academy, Kharkiv, Ukraine.

Khoroshun D. M. - Post-graduate student of the department of heat and Power Engineering and Energy Saving Technologies of Ukrainian Engineering and Pedagogics Academy, Kharkiv, Ukraine.

Fursova T. N. - PhD, Associate Professor, Associate Professor of the Department of Heat and Power Engineering and Energy Saving Technologies of Ukrainian Engineering and Pedagogics Academy, Kharkiv, Ukraine.

\section{ABSTRACT}

Context. Methods for the synthesis of precision electro-hydraulic control systems using the principle of multiplication are proposed. Use of the principle of multiplication allows to create compact control systems of technological objects, having high rates of precision and operation speed.

The problem of creating the unified basic software and hardware complex for precision automatic control systems and control of an optional technological object is considered.

On the basis of effective methods of the modern theory of optimal control, control algorithms have been developed that provide maximum compensation for all types of statistical and dynamic control errors.

Objective. The urgency of the work is due to the need to improve the precision of control systems of technological objects and the development of software and hardware complex for these systems.

Method. We have used the methods of optimal control, methods of structural synthesis. To confirm the validity of the developed models and principles, the method of experimental studies based on the operating equipment of test benches was used. To debug an experimental model of a basic software and hardware complex for testing the plain bearings of internal combustion engines, mathematical simulation of an electro-hydraulic drive was used. For the synthesis of a precision controller, the multiplication method was used.

Results. A number of standard sizes of high-speed precision EHSS based on part-turn hydraulic motors with a torque moment of up to $40 \mathrm{kNm}$ were developed, providing reproduction in the tracking mode of specified input effects with a bandwidth of up to 20 $\mathrm{Hz}$, positioning accuracy of up to one angular minute and a control range of up to $10^{4}$. Based on developed EHSS automated simulation dynamic stands were created and brought to practical use for testing mobile object guidance systems (Customer-Central Research Institute of Chemistry and Mechanics, Moscow) and the semi-axes transmission (Customer-JSC "KAMAZ", Naberezhnye Chelny). Based on the results of the research, a basic software and hardware complex for testing equipment of agricultural, automotive and other industries was created. The high-speed precision regulator for controlling the position of steam turbine actuator valves has been synthesized to compensate for all the main types of static and dynamic errors and more than double the performance compared to the base variant while maintaining acceptable stability margins (the results are used in promising projects of the State Energy Company "Centrenergo", National Nuclear Energy Generating Company "Energoatom", as well as in the Institute of Control Problems of the National Academy of Sciences of Ukraine.

Conclusions. The practical engineering methods for the synthesis of effective control laws of precision electro-hydraulic systems are proposed, as well as a number of effective regulators providing high characteristics of precision and operation speed. The principle of multiplicative control is proposed which allows to synthesize effective control algorithms for individual, autonomous, fully controlled and observable electro-hydraulic servo drive circuits based on third-order mathematical models. For selected autonomous control loops, effective control laws are obtained based on modal control methods and solving inverse problems of dynamics.

The proposed synthesis techniques are considered using the harmonic linearization method, the real nonlinear characteristics of the control signal power limitation, which allows determining the real rational ratios of the regulator parameters and real limiting precision and speed indicators, as well as preventing unwanted auto-oscillatory modes in the systems. In order to reduce the number of measured parameters used in the formation of the proposed control laws, on the basis of the well-known general principles of the synthesis of observing identification devices, the universal structures and formulas for calculating the parameters of standard models of autonomous control circuits of the EHSS were obtained. The method of autonomous testing and debugging of the EHSS control system using the electronic simulator of electro-hydraulic actuator has been improved which makes it possible to significantly reduce the time and cost involved in creating and engineering development a complex system.

KEYWORDS: unification, electro-hydraulic drives, automatic control systems, precision, operation speed, control algorithms.

\footnotetext{
ABBREVIATIONS

BSHC is a basic software and hardware complex;

EHD is a electro-hydraulic drive;

ECM is a electronic computing machine (a computer);

EHSS is a electro-hydraulic servo system;

RW is a research work;

EHA is a electro-hydraulic actuator. 


\section{NOMENCLATURE}

$X$ is a displacement (linear or angular) of the hydraulic motor working member;

$I$ is a coefficient of inertial load (mass or moment of inertia of moving parts reduced to the output link of the hydraulic motor);

$D$ is a coefficient of dissipative load (the coefficient of speed friction of translational or rotary motion);

$P$ is a factor of the positional load (linear or torsional rigidity);

$q$ is a characteristic parameter of the hydraulic motor (effective area of the hydraulic cylinder or specific volume of the hydraulic motor);

$\Delta p$ is a differential pressure on the hydraulic motor;

$K_{\mathrm{c}}, K_{\mathrm{f}}, K_{l}$ is a coefficient of compressibility of the working fluid, flow rate coefficient of the control valve and leakage coefficient;

$X_{\mathrm{cv}}$ is a displacement of the control valve of the servo valve;

$U_{\mathrm{v}}$ is a control voltage;

$K_{\mathrm{ux}}$ is a transmission ratio of the electromechanical servo valve converter;

$T_{\mathrm{o}}, \xi_{\mathrm{o}}, T_{\mathrm{a}}$ is a parameters of typical dynamic links (oscillatory and aperiodic), the serial connection of which describes the dynamic characteristic of the electromechanical servo valve converter;

$V_{c v}=\dot{X}_{c v}$ is a speed of the control valve;

$F_{\mathrm{c}}$ is a effective area of the hydraulic cylinder;

$V$ is a volume of working cavities and connecting channels of the hydraulic motor;

$\chi$ is a adiabatic module of the working fluid bulk elasticity;

$C$ is a position load factor;

$U_{v}^{\max }=5 B$ is a maximum control voltage in the input circuit of the servo valve;

$\vec{X}_{\text {set }}$ is vector of setting effects;

$\vec{X}_{\text {out }}$ is vector of output parameters;

$\vec{X}_{\text {in }}$ is vector of internal parameters.

\section{INTRODUCTION}

Having emerged recently in various industries large demands in test equipment of various functional purposes led to the idea of a modular concept for constructing test complexes of precision automatic controllers, in particular, for automatic control systems [1] whose main goal is to minimize and unify technical solutions as well as the elemental base used to create the test equipment. One of such elements (modules) in the overall structure of this concept is the basic software and hardware complex (BSHC) designed to control the electro-hydraulic drives of imitation dynamic stands. The development of the BSHC was carried out with the cooperation of the authors with the scientific and production enterprise "Teploavtomat" under a contract with the Ministry of Machine-Building Industry of Ukraine within the

\section{framework of the state program "Instrument} Engineering".

The object of study the automatic control system with an optional technological object of increased precision.

The subject of study: the processes of providing the precision and operation speed of regulation systems.

The purpose of the work creating the software and hardware complex for precision regulation and control systems, ensuring high precision and operation speed based on parametric synthesis and using multiplication methods.

\section{PROBLEM STATEMENT}

According to a vector of input (driving) effects $\vec{X}_{\text {set }}$ including the necessary set of kinematic $\left(X_{\text {set }}, \dot{X}_{\text {set }}, \ddot{X}_{\text {set }}\right)$ and power characteristics $\left(F_{\text {set }}, P_{\text {set }}\right)$ it is necessary to determine the law of control actions $\vec{U}_{\mathrm{y}}(t)$ that ensures the minimum (permissible) deviation of the corresponding components of the output parameters vector $\delta=\vec{X}_{\text {out }}-\vec{X}_{\text {set }}\left(\vec{X}_{\text {out }}\left\{X_{\text {out }}, \dot{X}_{\text {out }}, \ddot{X}_{\text {out }}, F_{\text {out }}, P_{\text {out }}\right\}\right)$ taking into account the technological and operational constraints vectors for input and internal parameters $\vec{X}_{\text {out }}^{\min } \leq \vec{X}_{\text {out }} \leq \vec{X}_{\text {out }}^{\max }, \quad \vec{X}_{\text {in }}^{\min } \leq \vec{X}_{\text {in }} \leq \vec{X}_{\text {in }}^{\max } . \quad$ The optimization criterion can be the minimum of the integral of the product of the absolute error and the time $I=\min \int|\varepsilon(t)| t d t \quad$ which provides the optimal compromise between static and dynamic accuracy.

\section{REVIEW OF THE LITERATURE}

A large number of works of a number of scientific schools and groups both in Ukraine and in the near and far abroad are devoted to the developments and research of the EHSS.

The initial scientific basis for the creation and study of EHSS should be considered the fundamental, universal work plan in the field of hydraulic drives, the theory of automatic control, technical cybernetics. Such works may include the works by G.I. Kaniuk [1, 2] in which the principles of creating high-speed precision electrohydraulic tracking systems in relation to test benches are considered. Special attention is paid to the improvement of electric and electro-hydraulic control systems [3, 4], their optimization $[5,6]$ and the improvement of the energy efficiency of their work [7]. About $90-95 \%$ of the regulators that are currently in operation use PID algorithms. In this regard, attention is paid to the use and improvement of PID controllers [8, 9]. The parameters of the regulators are optimized in order to improve the quality of regulation [10]. Various modifications of regulators are being studied $[11,12]$. The principle of robust control is successfully used, which allows improving the quality of regulation [13]. Studies are being conducted to improve the efficiency of management 
systems in various areas of economic activity, for example, in railway transport [14] and in energy [15].

Nevertheless, despite the large number of diverse, interesting and useful works in this area, currently there is not a sufficiently systematized and universal theoretical base for creating and researching precision high-speed EHSS, which complicates and slows down the processes of their development and implementation. Existing methods are either general metatheories that require filling with specific applied methods, mathematical models and technical solutions, or are aimed at solving particular problems: typical design engineering, verification calculations, and parametric optimization of already existing or designed systems. In this regard, applied theories and methodologies that would encompass all stages of creating high-speed precision EHSS are necessary.

\section{MATERIALS AND METHODS}

The aim of this work is the general presentation of the results of theoretical and experimental studies dedicated to the creation of the unified software and hardware complex for the precise control of electro-hydraulic servo systems of various functional purposes.

The BSHC includes the following main elements: a digital programmable set-point device which provides the formation of the required loading modes and emergency protection of the stand; a high-speed analog controller implementing efficient electro-hydraulic drive (EHD) control algorithms to provide the required dynamic characteristics of the test equipment; a personal computer that performs the functions of a top-level management system (coordination of several digital set-points in accordance with a specified test program, visual control, processing and registration of test results).

The general functional diagram of the BSHC is presented in Fig. 1.

Structurally the BSHC is a stand in which the following blocks are located: a microcontroller based on a single-chip microcomputer with an inter-module communication interface; blocks of analogue regulators; power unit; power amplifiers; power supplies; a network unit; a channel power transformer.

In the research plan the main problem in the creation of the BSHC was the development of an optimal structure of precision high-speed regulators since they play a major role in providing the required dynamic characteristics of the drives.

Taking into consideration quite high requirements to static and dynamic characteristics of electro-hydraulic drives, it was decided to use the following control algorithms in analogue controllers of the BSHC:

- the algorithm of proportional-differential-integral control by error (a proportional integral differential controller - PID-controller);

- the algorithm for state parameters of the EHD (a state controller) using the results of their direct measurements or the results of calculations based on the standard model (a state observer);

- the algorithm based on the method of solving the inverse problem of the dynamics of the EHD.

Comparative performance characteristics of various control algorithms of a standard size of the EHD of the simulation dynamic bench are presented in Fig. 2 .

The structure of analog regulators provides the possibility of use, if necessary, other types of control algorithms.

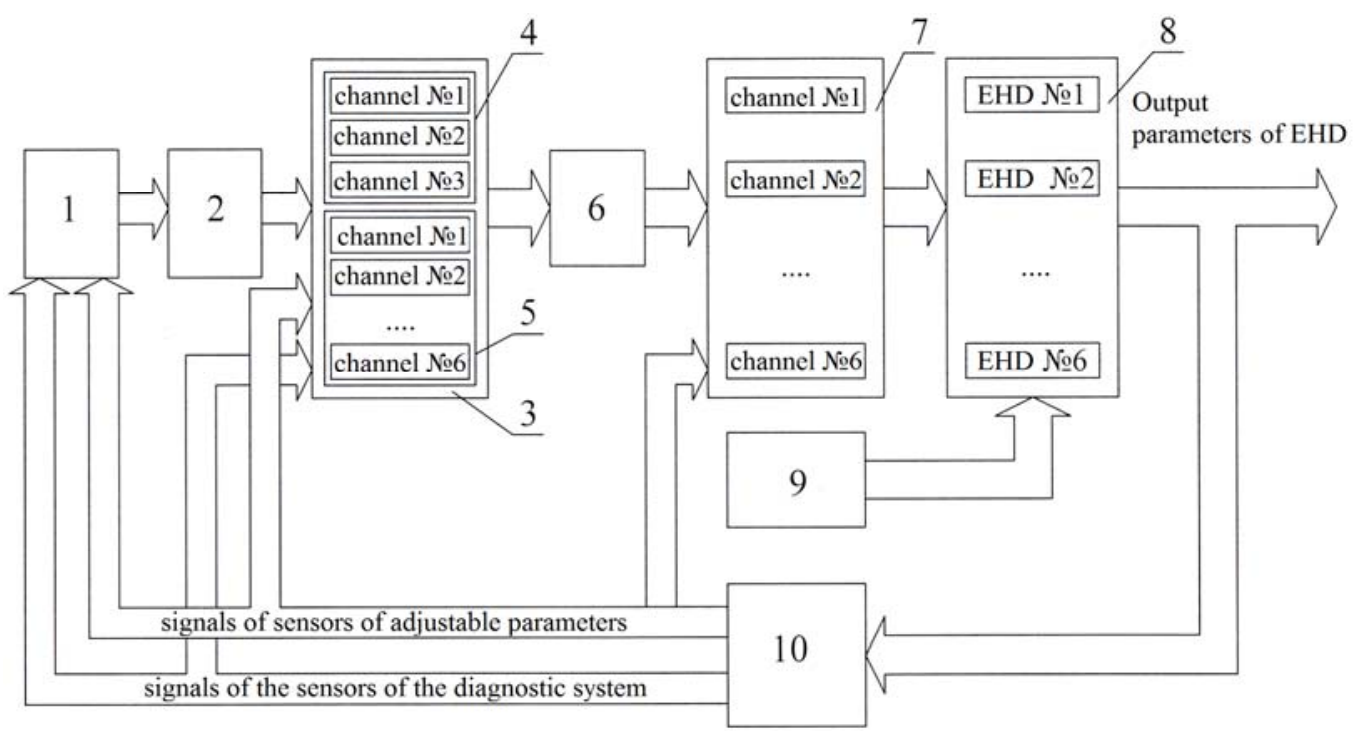

Figure 1 - The general functional diagram of the basic software and hardware control complex of electro-hydraulic drive test stands:

1 - upper-level control computer (personal computer); 2 - inter-module communication interface; 3 - digital programmable setpoint device; 4 - unit for setting the operating modes of the EHD; 5 - block of the control, diagnostics and indication of operating modes of the EHD; 6 - digital-to-analog converter; 7 - block of analog regulators; 8 - electro-hydraulic drives (EHD); 9 - analog generator of special signals; 10 - sensor of adjustable parameters and diagnostic systems 

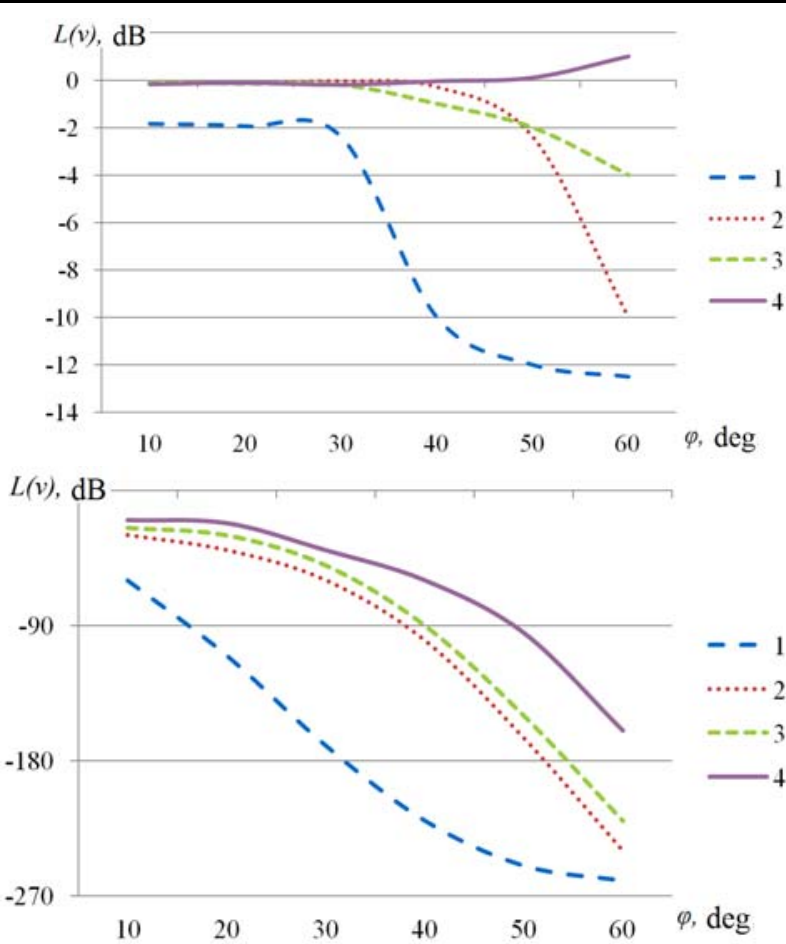

Figure 2 - Influence of various control laws on the dynamic characteristics of an electro-hydraulic drive:

1 - proportional regulator; 2 - PID controller;

3 - modal controller for three state parameters;

4 - regulator built on the principles of inverse dynamic problems

The general linearized mathematical model of the EHD including the executive hydraulic motor and the control servo valve can be represented as a system of usual differential equations of the sixth order [2]:

$$
\left\{\begin{array}{l}
I \ddot{X}+D \dot{X}+P X=q \Delta p, \\
K_{\mathrm{c}} \Delta \dot{p}=2 K_{f} X_{\mathrm{c} v}-2 q \dot{X}-K_{l} \Delta p, \\
T_{o} \ddot{X}_{\mathrm{c} v}+2 \xi_{o} T_{o} \dot{X}_{3}+X_{c v}=K_{\mathrm{uX}} U_{v}^{\prime}, \\
T_{\mathrm{a}} \dot{U}_{v}^{\prime}+U_{v}^{\prime}=U_{v} .
\end{array}\right.
$$

In this case, in order to ensure a set quality control in the high-frequency region, the control algorithms used in analog regulators must also have a minimum of sixth order. At the same time the procedures of theoretical synthesis and practical adjustment of regulators are significantly complicated. However, when proportional servo valves with a high pass-band are used in the EHD (Fig. 3), the control valve position is equipped with sensors, it is possible to reduce the order of the regulators by using the principle of multiplicative control (separate control of the positions of the control valve and hydraulic motor [2]). In this case separate circuits can operate from two autonomously adjusted regulators of the third (or, depending on the type of load and range of reproduced frequencies, and lower) of the order of one type or another.

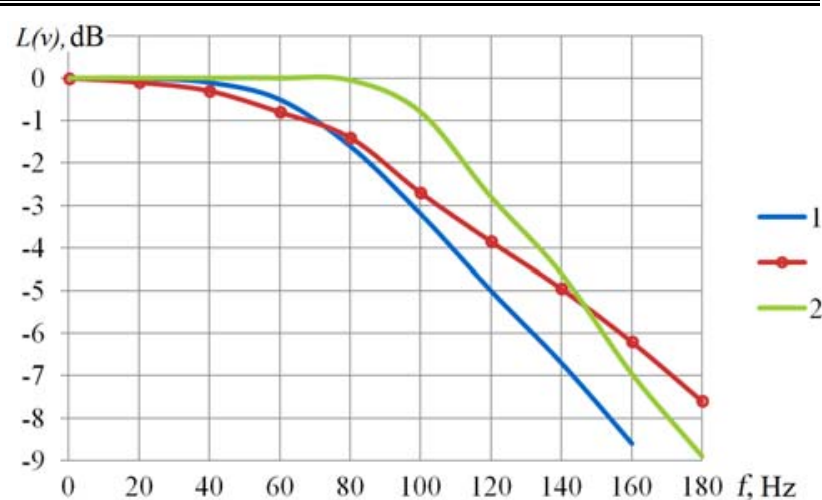

Figure 3 - Amplitude-frequency characteristics of the servo valve УЭГ-СВ-100:

- $\mathrm{O}$ without correction, experiment; 1 - without correction, calculation (approximation by the vibrational link $T=1.67 \cdot 10 \mathrm{~s}$, $\xi=0,7) ; 2-$ correction with the help of PID-controller $(K=300$, $\left.T_{\mathrm{d}}=0.07 \mathrm{c}, T_{\mathrm{e}}=0.3 \mathrm{~s}\right)$

\section{EXPERIMENTS}

Development and debugging of the experimental the BSHC sample were carried out using the mathematical and electronic model (simulator) of the electro-hydraulic drive of the test stand for testing the plain bearings of internal combustion engines of trucks. The EHD of such a stand is a hydraulic cylinder with a control servo valve designed to reproduce dynamic loads acting on the crankshaft main bearings. The range of reproducible loads is 50 tons, the required drive bandwidth is $100 \mathrm{~Hz}$.

Estimated calculations have shown that the main load is due to the rigidity of the test objects (thus, the load is mainly positional). Calculations showed that using the principle of multiplicative control, it is possible to reduce the dynamic distortion of the output parameter of the servo valve (this task was solved by including the PID controller in the autonomous regulation circuit of the control valve). Figure 4 presents the amplitude-frequency characteristics of the servo valve with a contour of autonomous correction of the control valve position and without it.

It follows from the graphs that the dynamical characteristic of the servo valve in the required frequency range (up to $100 \mathrm{~Hz}$ ) corrected by the PID-controller can be satisfactorily described by the oscillating link with the values of the time constant $T_{\mathrm{c}}$ and the relative damping factor $\xi_{\mathrm{k}}$, respectively $1 \cdot 10^{-3} \mathrm{~s}$ and 0.7 . In this case, taking into consideration the positional character of the main load, the general mathematical model of the EHD in matrix form and taking into account the control voltage limit in the input circuit of the servo valve takes the form:

$$
\begin{gathered}
\left(\begin{array}{l}
\dot{H} \\
\dot{X}_{c v} \\
\dot{V}_{c v}
\end{array}\right)=\left(\begin{array}{rrr}
-\frac{1}{T_{h}} & \frac{K_{h}}{T_{h}} & 0 \\
0 & 0 & 1 \\
0 & -\frac{1}{T_{\mathrm{\kappa}}^{2}} & -2 \xi_{o}
\end{array}\right)\left(\begin{array}{l}
H \\
X_{c v} \\
V_{c v}
\end{array}\right)+\left(\begin{array}{lll}
0 & 0 & \frac{K_{\mathrm{ux}}}{T_{o}^{2}}
\end{array}\right)\left(\begin{array}{l}
0 \\
0 \\
U_{v}
\end{array}\right), \\
\left|U_{v}\right| \leq U_{v}^{\max }
\end{gathered}
$$




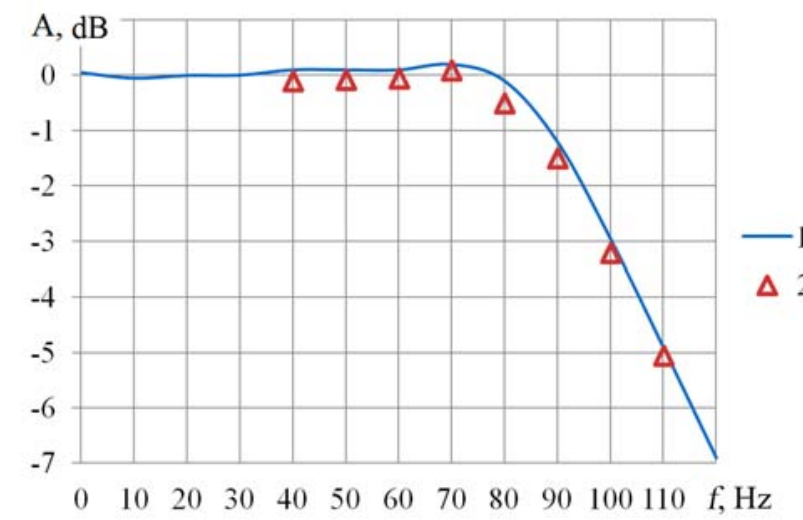

Figure 4 - Amplitude-frequency characteristic of the electrohydraulic drive with the PID-controller:

1 - calculation, 2 - experiment

The load on the rod of the hydraulic cylinder:

$$
H=F_{c} \Delta P \text {. }
$$

The time constant and the static transmission ratio of the hydraulic motor:

$$
\begin{gathered}
T_{h}=F_{c}\left(0,5 \frac{V}{\chi F_{c}}+\frac{2 F_{c}}{C}\right) / K_{\mathrm{y}} \\
K_{h}=2 K_{\mathrm{x}} F_{c} / K_{\mathrm{y}} .
\end{gathered}
$$

Calculations showed that the use of a PID-controller with gain values, time constants of the differentiating and integrating link is $10 \mathrm{~V} / \mathrm{V}$ respectively; $0.1 \mathrm{~s}$ and $5 \cdot 10^{-3} \mathrm{~s}$, it is possible to obtain the required bandwidth (about 100 $\mathrm{Hz}$ ) for the adopted the EHP model (Fig. 4).

After fabricating and debugging of the experimental BSHC sample, its functional and dynamic characteristics were verified by laboratory tests at the research-andproduction enterprise "Teploavtomat" using an electronic model (simulator) of the EHD, the structure and parameters of which corresponded to the mathematical model. The test results confirmed the calculated bandwidth of the EHD.

\section{RESULTS}

Conducted studies have allowed us to obtain the following results:

- a number of standard sizes of the high-speed precision EHSS based on incomplete rotating hydraulic motors with a torque range of up to $40 \mathrm{kNm}$ was developed, ensuring the reproduction in the tracking mode of specified input effects with a bandwidth of up to $20 \mathrm{~Hz}$, positioning precision of up to one corner minute and control range up to $10^{4}$;

- on the basis of the developed EHSS, automated simulated dynamic test stands for testing of guidance systems for mobile objects (the customer - Central Research Institute of Chemistry and Mechanics, Moscow) and for testing semi-axle transmissions (the customer Publicly Traded Company "KAMAZ", Naberezhnye Chelny) were created and brought to practical use.

\section{DISCUSSION}

As a result of a series of theoretical and experimental studies carried out within the framework of state budget research (the customer - Ministry of Education and Science of Ukraine) on the basis of solving the inverse problem of dynamics, the high-speed precision controller for the control loop of the position of the steam turbine actuator valves was synthesized, which compensates all major types of static and dynamic errors and more than a twofold increase in operation speed compared with the baseline while maintaining the permissible reserves of stability (the results of the work are used in long-term projects of the State energy company "Centrenergo" NNEGC "Energoatom" and "Institute of Control Problems of the National Academy of Sciences of Ukraine".

All developments and technical solutions have been tested experimentally (research tests and acceptance tests) and implemented at customer enterprises, which confirms the reliability and practical value of the scientific positions and results as well as determines the possibility of their further effective use when creating the high-speed precision EHSS for various fields of technology in order to increase the productivity and precision of technological equipment, increase energy - and resource indicators of production.

Experimental studies and practical engineering confirmed that the developed scientific positions and the results of the work generally provide the effective practical results consisting in a significant reduction of the time and money spent on the creation and completion of new facilities due to the systematization and unification of the most responsible and knowledge-intensive stages of the design of the EHSS (a technical project and proposal).

The results of the work were used in the implementation of a number of fundamental and applied research to create the high-speed precision EHSS of imitation dynamic stands for enterprises of the defense and engineering industries.

\section{CONCLUSIONS}

Based on the well-known general principles of the modern theory of optimal control, practical engineering techniques for synthesizing effective laws of controling the precision electro-hydraulic systems, as well as a number of effective regulators that provide high (approaching to the utmost in energy capabilities) characteristics of precision and operation speed are proposed.

\section{Scientific novelty:}

- the principle of multiplicative control is proposed, which makes it possible to synthesize effective control algorithms for the individual, autonomous, fully controllable and observable EHSS circuits based on third-order mathematical models;

- for the selected autonomous control loops, effective control laws are obtained on the basis of modal control methods and solving inverse dynamic problems (including calculation formulas for choosing optimal parameters of regulator parameters);

- in contrast to the existing methods of the linear theory of optimal control, the proposed methods of synthesis take into account, with the help of the method of harmonic linearization, real nonlinear characteristics of the control 
power limit, which allows to determine the real rational relations of the regulator parameters and the real limit values of precision and operation speed, and also to prevent the occurrence of undesirable self-oscillatory regimes in systems;

- in order to reduce the number of measured parameters used in the formation of the proposed control laws, universal structures and formulas for calculating the parameters of reference models (state monitors) of autonomous EHSS control loops have been obtained on the basis of known general principles for the synthesis of observing identification devices.

Practical value: The technique of autonomous testing and debugging of the EHSS control system using the electronic simulator EHA is improved, which allows to significantly reduce the time and money spent on the creation and completion of the complex system.

Prospects for further research: The use of the proposed methods to create precision high-speed control systems of technological objects in various sectors of economic activity.

\section{ACKNOWLEDGEMENTS}

The work was supported by the State research project: "Development of the theoretical foundations and practical principles of the creation of precision high-speed electrohydraulic tracking systems for energy and resource saving", registration number $0109 \mathrm{U} 008660$.

The authors are also grateful to the Zmiivska thermal power plant (TPP) on the base of which research was carried out that found their introduction when implementing business contracts on the following topics: "Development of the practical principles of energy-saving control systems integration in the automated control systems of technological processes of the Zmiivska TPP power units” № 14-10-15/87 and "Development of complex measures for improving the technical and economic characteristics of the Zmiivska TPP power units” № 16-28-15/751.

\section{REFERENCES}

1. Kaniuk G. I. High-speed precision electrohydraulic servo systems (ECGS). Fundamentals of the theory. Development. Research. Monograph. Kharkov, Publishing house "Point", 2008, 108 p.

2. Kaniuk G. I., Osadchiy A. Kh., Katykhin K. N., A.N. Shuvanov and et al. Basic program-technical complex for control of electrohydraulic drives of test stands, Bulletin of Science and Technology. Kharkov, 1997, Issue 2, P. 15-18

3. Titarenko V. B. Increasing the energy efficiency of volume hydraulic drives, Young Scientist, 2017, No. 51, pp. 97-99.

4. Johnson J. Engineering Essentials: Electrohydraulic Motion Control. Hydraulics \& Pneumatics. Jan 01, 2012 https://www.hydraulicspneumatics.com/200/FPE/SystemDesign/Art icle/False/6463/FPE-SystemDesign

5. Walters R. B. Hydraulic and Electric-Hydraulic Control Systems. Springer Science+Business Media B.V., 2000. ISBN 978-94-0159429-5

6. Banyai, D. Vaida, L. Electro-hydraulic Control System For Variable Displacement Machines 12th International Conference "Automation in Production Planning and Manufacturing", Zilina, 2011.

7. Watton J. Electrohydraulic Control System: Principles Of Operation, Circuit Analysis \& Design. 2016. ISBN 978-87-4031187-7

8. Eker İ. Robust governor design for hydro turbines using a multivariable-cascade control approach. The Arabian Journal for Science and Engineering, 2003, Vol. 28, No. 28.

9. Astrom K. J., Hagglund T. Advanced PID control. SA, The Instrumentation, Systems, and Automation Society, 2006, 460 p. URL: https://www.twirpx.com/file/162015/ (data zvernennya: 10.04.2016).

10. Severin V. P., Nikulina E. N. Vector target functions for optimizating the quality indicators of automatic regulation systems, The Bulletin of the National Technical University "Kharkiv Polytechnic Institute". Kharkiv, Issue 55, 2005, pp. 139-144.

11. Guillermo J. Silva, Aniruddha, Datta, \& S. P. Bhattacharyya New Results on the Synthesis of PID Controllers, IEEE transactions on automatic control, Vol. 47, No. 2, February 2002. URL: https://wenku.baidu.com/view/a4e2c3619b6648d7c1c74632.html (data zvernennya: 10.04.2016).

12. Leva A., Cox C., \& Ruano A. Hands-on PID autotuning: a guide to better utilization. IFAC Professional Brief. URL: http://www.ifaccontrol.org (data zvernennya: 10.04.2016).

13. Eker İ. Robust governor design for hydro turbines using a multivariable-cascade control approach. The Arabian Journal for Science and Engineering, 2003, Vol. 28, No. 28.

14. Stasiuk A. I., Goncharova L. L. Mathematical models and methods of analyzing computer networks for controlling the power supply of railways, Cybernetics and Systems Analysis, 2018, Vol. 54, No. 1, pp. $184-192$.

15. Artiukh S. F., Kaniuk G. I., Mezeria A. Yu., Popov M. A., Bliznichenko E. N. Efficient energy-saving control of electrohydraulic servo systems. Monograph. Kharkov, Izd. "Point", 2012, 120 p. ISBN 978-617-669-019-1

Received 09.10.2018 Accepted 16.12.2018.

удК 658.5.011.56

\section{УНІФІКОВАНИЙ БАЗОВИЙ ПРОГРАМНО-ТЕХНІЧНИЙ КОМПЛЕКС ДЛЯ ПРЕЦИЗІЙНИХ} ЕНЕРГОЗБЕРІГАЮЧИХ СИСТЕМ АВТОМАТИЧНОГО РЕГУЛЮВАННЯ ТА УПРАВЛІННЯ

Канюк Г. І. - д-р техн. наук, професор, завідувач кафедри теплоенергетики та енергозберігаючих технологій Української інженерно-педагогічної академії, Харків, Україна.

Мезеря А. Ю. - канд. техн. наук, доцент, доцент кафедри теплоенергетики та енергозберігаючих технологій Української інженерно-педагогічної академії, Харків, Україна.

Князєва В. М. - аспірант кафедри теплоенергетики та енергозберігаючих технологій Української інженерно-педагогічної академії, Харків, Україна.

Хорошун Д. М. - аспірант кафедри теплоенергетики та енергозберігаючих технологій Української інженерно-педагогічної академії, Харків, Україна.

Фурсова Т. М. - доцент кафедри теплоенергетики та енергозберігаючих технологій Української інженерно-педагогічної академії, Харків, Україна.

\section{АНОТАЦІЯ}

Запропоновано методи синтезу прецизійних електрогідравлічних систем управління з використанням принципу мультиплікації. Використання принципу мультиплікації дозволяє створювати компактні системи управління технологічними об'єктами, мають високі показники точності і швидкодії.

Розглянуто задачу створення уніфікованого базового програмно-технічного комплексу для прецизійних систем автоматичного регулювання та керування довільним технологічним об’єктом.

На основі ефективних методів сучасної теорії оптимального управління розроблені алгоритми управління, що забезпечують максимальну компенсацію всіх видів статистичних і динамічних помилок управління.

C Kaniuk G. I., Mezeria A. Yu, Kniazieva V. N., Khoroshun D. M., Fursova T. N., 2019

DOI 10.15588/1607-3274-2019-2-21 
Об’єкт дослідження: система автоматичного регулювання довільним технологічним об'єктом підвищеної точності.

Предмет дослідження: процеси забезпечення точності і швидкодії систем регулювання.

Мета: створення програмно-технічного комплексу, для прецизійних систем регулювання і управління, що забезпечує високі показники точності і швидкодії, на основі параметричного синтезу і використання методів мультиплікації.

Актуальність. Актуальність роботи обумовлена необхідністю підвищення точності систем керування технологічними об'єктами і розробки програмно-технічного комплексу для цих систем.

Метод. В роботі використовувалися методи оптимального управління, методи структурного синтезу. Для підтвердження достовірності розроблених моделей і принципів, використовувався метод експериментальних досліджень на базі діючого обладнання випробувальних стендів. Для налагодження експериментального зразка базового програмно-технічного комплексу для випробувань підшипників ковзання двигунів внутрішнього згоряння використовувалося математичне імітаційне моделювання електрогідравлічного приводу. Для синтезу прецизійного регулятора використовувався метод мультиплікації.

Результати. Розроблено ряд типорозмірів швидкодіючих прецизійних ЕГСС на базі неполноповоротние гідродвигунів 3 діапазоном крутних моментів до 40 кНм, що забезпечують відтворення в стежить режимі заданих вхідних впливів 3 пропускною здатністю до 20 Гц, точністю позиціонування до однієї кутової хвилини і діапазоном регулювання до 104. На базі розроблених ЕГСС створені і доведені до практичного використання автоматизовані імітаційні динамічні стенди для випробування систем наведення мобільних об’єктів (замовник - ЦНІІХМ, м. Москва) і для випробування піввісь трансмісій (замовник - АТ «КамАЗ», м. Набережні Челни). На основі результатів виконаних досліджень створено базовий програмно-технічний комплекс для випробувального обладнання підприємств сільськогосподарської, автомобільної та інших галузей промисловості. Синтезований швидкодіючий прецизійний регулятор контуру управління становищем регулюючих клапанів парової турбіни, що забезпечує компенсацію всіх основних видів статичних і динамічних помилок і більш ніж дворазове підвищення швидкодії в порівнянні з базовим варіантом при збереженні допустимих запасів стійкості (результати робіт використовуються в перспективних проектах Державної енергетичної компанії «Центренерго», НАЕК «Енергоатом», а також в МГП «Інститут проблем управління НАН України».

Висновки. Запропоновано практичні інженерні методики синтезу ефективних законів управління прецизійними електрогідравлічними системами, а також ряд ефективних регуляторів, що забезпечують високі характеристики точності і швидкодії. Запропоновано принцип мультиплікативного управління, що дозволяє синтезувати ефективні алгоритми управління окремими, автономними, повністю керованими і спостережуваними контурами ЕГСП на основі математичних моделей третього порядку. Для виділених автономних контурів управління отримані ефективні закони управління на основі методів модального управління і розв'язку обернених задач динаміки.У запропонованих методиках синтезу враховані, за допомогою методу гармонійної лінеаризації, реальні нелінійні характеристики обмеження потужності керуючого сигналу, що дозволяє визначати реальні раціональні співвідношення параметрів регуляторів і реальні граничні показники точності і швидкодії, а також запобігати виникненню небажаних автоколивальних режимів у системах. 3 метою зменшення кількості вимірюваних параметрів, використовуваних при формуванні запропонованих законів управління, на основі відомих загальних принципів синтезу спостерігають пристроїв ідентифікації отримані універсальні структури і формули для розрахунку параметрів еталонних моделей автономних контурів управління ЕГСС. Удосконалено методику автономних випробувань і налагодження системи управління ЕГСС з використанням електронного імітатора ЕГІМ, що дозволяє істотно скоротити витрати часу і коштів на створення і доведення комплексної системи.

КЛЮЧОВІ СЛОВА: уніфікація, електрогідравлічні приводи, системи автоматичного управління, точність регулювання, швидкодія, алгоритми управління.

\section{УДК 658.5.011.56 \\ УНИФИЦИРОВАННЫЙ БАЗОВЫЙ ПРОГРАММНО-ТЕХНИЧЕСКИЙ КОМПЛЕКС ДЛЯ ПРЕЦИЗИОННЫХ ЭНЕРГОСБЕРЕГАЮЩИХ СИСТЕМ АВТОМАТИЧЕСКОГО РЕГУЛИРОВАНИЯ И УПРАВЛЕНИЯ}

Канюк Г. И. - д-р техн. наук, профессор, заведующий кафедрой теплоэнергетики и энергосберегающих технологий Украинской инженерно-педагогической академии, Харьков, Украина.

Мезеря А. Ю. - канд. техн. наук, доцент, доцент кафедры теплоэнергетики и энергосберегающих технологий Украинской инженерно-педагогической академии, Харьков, Украина.

Князева В. Н. - аспирант кафедры теплоэнергетики и энергосберегающих технологий Украинской инженерно-педагогической академии, Харьков, Украина.

Хорошун Д. М. - аспирант кафедры теплоэнергетики и энергосберегающих технологий Украинской инженернопедагогической академии, Харьков, Украина.

Фурсова Т. Н. - доцент кафедры теплоэнергетики и энергосберегающих технологий Украинской инженерно-педагогической академии, Харьков, Украина.

Предложены методы синтеза прецизионных электрогидравлических систем управления с использованием принципа мультипликации. Использование принципа мультипликации позволяет создавать компактные системы управления технологическими объектами, обладают высокими показателями точности и быстродействия.

Рассмотрена задача создания унифицированного базового программно-технического комплекса для прецизионных систем автоматического регулирования и управления произвольным технологическим объектом.

На основе эффективных методов современной теории оптимального управления разработаны алгоритмы управления, обеспечивающие максимальную компенсацию всех видов статистических и динамических ошибок управления.

Объект исследования: система автоматического регулирования произвольным технологическим объектом повышенной точности.

Предмет исследования: процессы обеспечения точности и быстродействия систем регулирования.

Цель: создания программно-технического комплекса, для прецизионных систем регулирования и управления, обеспечивающего высокие показатели точности и быстродействия, на основе параметрического синтеза и использования методов мультипликации.

Актуальность. Актуальность работы обусловлена необходимостью повышения точности систем управления технологическими объектами и разработки программно-технического комплекса для этих систем. 
Метод. В работе использовались методы оптимального управления, методы структурного синтеза. Для подтверждения достоверности разработанных моделей и принципов, использовался метод экспериментальных исследований на базе действующего оборудования испытательных стендов. Для отладка экспериментального образца базового программно-технического комплекса для испытаний подшипников скольжения двигателей внутреннего сгорания использовалось математическое имитационное моделирование электрогидравлического привода. Для синтеза прецизионного регулятора использовался метод мультипликации.

Результаты. Разработан ряд типоразмеров быстродействующих прецизионных ЭГСС на базе неполноповоротных гидродвигателей с диапазоном крутящих моментов до 40 кНм, обеспечивающих воспроизведение в следящем режиме заданных входных воздействий с полосой пропускания до 20 Гц, точностью позиционирования до одной угловой минуты и диапазоном регулирования до $10^{4}$. На базе разработанных ЭГСС созданы и доведены до практического использования автоматизированные имитационные динамические стенды для испытания систем наведения мобильных объектов (заказчик - ЦНИИХМ, г. Москва) и для испытания полуосей трансмиссий (заказчик - АО «КамАЗ», г. Набережные Челны). На основе результатов выполненных исследований создан базовый программно-технический комплекс для испытательного оборудования предприятий сельскохозяйственной, автомобильной и других отраслей промышленности. Синтезирован быстродействующий прецизионный регулятор контура управления положением регулирующих клапанов паровой турбины, обеспечивающий компенсацию всех основных видов статических и динамических ошибок и более чем двукратное повышение быстродействия по сравнению с базовым вариантом при сохранении допустимых запасов устойчивости (результаты работ используются в перспективных проектах Государственной энергетической компании «Центрэнерго», НАЭК «Энергоатом», а также в МГП «Институт проблем управления НАН Украины».

Выводы. Предложены практические инженерные методики синтеза эффективных законов управления прецизионными электрогидравлическими системами, а также ряд эффективных регуляторов, обеспечивающих высокие характеристики точности и быстродействия. Предложен принцип мультипликативного управления, позволяющий синтезировать эффективные алгоритмы управления отдельными, автономными, полностью управляемыми и наблюдаемыми контурами ЭГСП на основе математических моделей третьего порядка. Для выделенных автономных контуров управления получены эффективные законы управления на основе методов модального управления и решения обратных задач динамики. В предложенных методиках синтеза учтены, при помощи метода гармонической линеаризации, реальные нелинейные характеристики ограничения мощности управляющего сигнала, что позволяет определять реальные рациональные соотношения параметров регуляторов и реальные предельные показатели точности и быстродействия, а также предотвращать возникновение нежелательных автоколебательных режимов в системах. С целью уменьшения количества измеряемых параметров, используемых при формировании предложенных законов управления, на основе известных общих принципов синтеза наблюдающих устройств идентификации получены универсальные структуры и формулы для расчета параметров эталонных моделей автономных контуров управления ЭГСС. Усовершенствована методика автономных испытаний и отладки системы управления ЭГСС с использованием электронного имитатора ЭГИМ, позволяющая существенно сократить затраты времени и средств на создание и доводку комплексной системы.

КЛЮЧЕВЫЕ СЛОВА: унификация, электрогидравлические приводы, системы автоматического управления, точность регулирования, быстродействие, алгоритмы управления.

\section{ЛІТЕРАТУРА / ЛИТЕРАТУРА}

1. Канюк Г. И. Быстродействующие прецизионные электрогидравлические следящие системы (ЭГСС). Основы теории. Разработка. Исследования : монография / Г. И. Канюк. - Х. : Издательство НТМТ, 2008. - 108 р.

2. Базовый программно-технический комплекс для управления электрогидравлическими приводами испытательных стендов [Г. И. Канюк, А. Х. Осадчий, К. Н. Катыхин и др.] // Вестник науки и техники. - 1997. - Вып. 2. - С. 15-18.

3. Титаренко В. Б. Повышение энергоэффективности объемных гидроприводов [Электронный ресурс] / В. Б. Титаренко. Молодой ученый. - 2017. - № 51. - С. 97-99. URL https://moluch.ru/archive/185/47487/ (дата обращения: 18.11.2018).

4. Johnson J. Engineering Essentials: Electrohydraulic Motion Control. Hydraulics \& Pneumatics. [Electronic resource] / J. Johnson. Acces mode: https://www.hydraulicspneumatics.com/200/FPE/SystemDesign/Art icle/False/6463/FPE-SystemDesign

5. Walters R. B. Hydraulic and Electric-Hydraulic Control Systems R. B. Walters. - Springer Science+Business Media B. V., 2000. ISBN 978-94-015-9429-5

6. Banyai D. Electro-hydraulic Control System For Variable Displacement Machines 12th International Conference "Automation in Production Planning and Manufacturing" / D. Banyai, L. Vaida // Conference. - Zilina, 2011

7. Watton J. Electrohydraulic Control System: Principles Of Operation, Circuit Analysis \& Design / J. Watton. - 2016. ISBN 978-87-403-1187-7

8. Eker İ. Robust governor design for hydro turbines using a multivariable-cascade control approach / İ. Eker // The Arabian Journal for Science and Engineering. - 2003. - Vol. 28, No. 28.
9. Astrom K. J. Advanced PID control. SA. The Instrumentation, Systems, and Automation Society [Electronic resource] / K. J. Astrom, T. Hagglund, 2006 - 460 p. URL: https:/www.twirpx.com/file/162015/ (дата звернення: 10.04.2016).

10. Северин В. П. Векторные целевые функции для оптимизации показателей качества систем автоматического регулирования / В. П. Северин, Е. Н. Никулина // Вестник национального технического университета «ХПИ». - Вып. 55. - Харьков. 2005. - C. 139-144.

11. Guillermo. Bhattacharyya New Results on the Synthesis of PID Controllers [Electronic resource] / Guillermo, J. Silva, Aniruddha, Datta, \& S. P. // IEEE transactions on automatic control. - 2002. No. $2 . \quad$ URL: https://wenku.baidu.com/view/a4e2c3619b6648d7c1c74632.html (дата звернення: 10.04.2016).

12. Leva A. Hands-on PID autotuning: a guide to better utilization [Electronic resource] / A. Leva, C. Cox \& A. Ruano // IFAC Professional Brief. URL: http://www.ifac-control.org (дата звернення: 10.04.2016).

13. Eker İ. Robust governor design for hydro turbines using a multivariable-cascade control approach / İ. Eker // The Arabian Journal for Science and Engineering. - 2003. - Vol. 28, No. 28.

14. Стасюк А. И. Математические модели и методы анализа компьютерных сетей управления электроснабжением железных дорог / А. И. Стасюк, Л. Л. Гончарова // Кибернетика и системный анализ. - 2018. - Том 54, № 1. - С. 184-192.

15. Эффективное энергосберегающее управление электрогидравлическими следящими системами : монография / [С. Ф. Артюх, Г. И. Канюк, А. Ю. Мезеря и др.]. - Харьков : Изд. «Точка», 2012. -120 c. ISBN 978-617-669-019-1 